Relations industrielles

Industrial Relations

\title{
Creese, Gillian, Contracting Masculinity: Gender, Class and Race in a White-Collar Union, 1944-1994
}

\section{Ken Cruikshank}

Volume 55, numéro 3, 2000

URI : https://id.erudit.org/iderudit/051344ar

DOI : https://doi.org/10.7202/051344ar

Aller au sommaire du numéro

Éditeur(s)

Département des relations industrielles de l'Université Laval

ISSN

0034-379X (imprimé)

1703-8138 (numérique)

Découvrir la revue

Citer ce compte rendu

Cruikshank, K. (2000). Compte rendu de [Creese, Gillian, Contracting

Masculinity: Gender, Class and Race in a White-Collar Union, 1944-1994].

Relations industrielles / Industrial Relations, 55(3), 555-557.

https://doi.org/10.7202/051344ar

Tous droits réservés @ C Département des relations industrielles de l'Université Laval, 2000
Ce document est protégé par la loi sur le droit d'auteur. L’utilisation des services d'Érudit (y compris la reproduction) est assujettie à sa politique d'utilisation que vous pouvez consulter en ligne.

https://apropos.erudit.org/fr/usagers/politique-dutilisation/ 
(by McAllister) shows how the highly educated workforce, discussed in the previous chapter, is not much different from the warehouse workers studied in this chapter. Chapter 10 (by Rebitzer) examines the job safety of contract workers - a much less studied factor - through a case study of the petrochemical industry.

Part 4 includes two chapters on policy, with Chapter 11 (by duRivage, Carré and Tilly) discussing labour law and part-time and contingent workers and Chapter 12 (by Carnevale, Jennings and Eisenmann) examining contingent workers within the employment law. Needless to say, both chapters argue that laws do not adequately cover contingent workers. In particular, the outdated concept of the employment relationship emerges as one of the hurdles to legal coverage. The last chapter of this volume (Chapter 13 by Barker and Christensen) provides summary findings and raises research questions.

The editors are to be congratulated for bringing researchers from a variety of disciplines to examine this important change in American employment relationships. I found each chapter in this book to be informative, providing answers to the questions editors proposed in the introductory chapter. However, each chapter seemed to stand alone without a clear identifying theme across chapters. The first chapter suggested an overall contextual analysis of the issues but such an analysis was not used in most other chapters. Moreover, the book is primarily on the 'bad jobs' of contingent work that the transitions in American workplaces have created. There are some, even if small in number, of 'good jobs' in temporary, self-employed contract and regular part-time work. It seems like the editors omitted these by choice, but explaining that fact - at least in the introductory chapter - could have contributed to the value of the book. Still, there was much to learn or to reaffirm existing knowledge in this book. I recommend it to researchers and practitioners interested in the topic of contingent work. For readers outside the U.S., the book also offers valuable information on the transformation in American employment relations.

ISIK URLA ZEYTINOGLU McMaster University

\section{Contracting Masculinity: Gender, Class and Race in a White-Collar Union, 1944-1994 \\ by Gillian CReESE, Don Mills, Ont.: Oxford University Press Canada, 1999, 279 p., ISBN 0-19-54154-3.}

Contracting Masculinity is a fascinating and provocative analysis of the role played by a trade union in structuring the workplace and the workforce. Gillian Creese effectively demonstrates that a union of office employees at British Columbia Hydro built and reinforced the segregation of "men's" and "women's" work in the practices it followed and, more importantly, in the contracts that it negotiated. Creese also is attentive to segregation by race, and reminds readers that the B.C. labour movement historically supported the exclusion of Asian workers. Until very recently, however, this particular union of clerical workers played little role, one way or another, in shaping the racist hiring practices of its employer. Contracting Masculinity therefore has much more to say about gender.

Creese has selected a very useful case study for her exploration of the gendered nature of trade union activity. Because of the feminization of some clerical work, between 40 to $55 \%$ of the workers within this white collar union were women. Creese therefore can very clearly compare their experiences with the men within the union, and few will 
be surprised by the overall patterns she finds. Within the hierarchy of office work, women overwhelmingly dominated the lower status and lower paid jobs. Even as more married women remained in the workforce during the 1950 s and 1960 s, they did not move up the hierarchy and continued to face lower salaries and more limited career prospects than their male counterparts. In spite of apparent changes in attitudes towards working women and legislation governing them, what was true in 1949 continued largely to be true in 1966 , 1981 and 1991.

Why did women continue to occupy office "jobs" as opposed to men, who appear to have enjoyed more promising and better paying office "careers"? It is Creese's answer to this question which makes the book of such interest to specialists in industrial relations. Without denying that the broader social context may be important, Creese argues that a good part of the answer can be found in the details of bargaining, negotiated contracts and, most particularly, the process of evaluating jobs and determining job classifications. She meticulously documents the "very concrete ways" in which Local 378 of the Office and Technical Employees' Union, 'negotiated racialized-gender relations among its members at the same time that it negotiated general conditions of work with its employer." (p. 55) Using some interviews and very impressive archives of union material, Creese is able to trace the union's bargaining positions and strategies over a 40 -year period. Beginning with one of their first demands, that married women should be excluded from the workforce, the union actively reinforced the gendered division of labour.

Creese's analysis shows the significance of taking history seriously. She is able to demonstrate that the initial job evaluation system designed in the $1940 \mathrm{~s}$ was as much concerned with protecting the incomes of the "male breadwinner" as was the differential wage then offered men and women in the same jobs. Although women in the union did object to the blatent discrimination of the differential, Creese suggested that they do not seem to have objected to the overall thrust of the male breadwinner argument. The problem was that, while after a considerable struggle the wage differential finally was eliminated, "the union's role in establishing the gendered division of labour [through job classifications] ceased to be visible in bargaining" for decades. Although amended and altered a variety of times, the job classification of the $1940 \mathrm{~s}$ continued to shape the nature of men's and women's work at BC Hydro. The "technical career ladder" which emerged from negotiations appeared to be gender-neutral and scientific, but effectively worked as "a preferential system of training and promotions for men." As a result of history, therefore, trade unionists who championed the job classification system thought of themselves as fighting for the rights of all workers. Even when women became more active in the union in the 1970s, male and even some female trade unionists thought of other matters as women's issues, rather than focusing on the discriminatory classification system.

What makes this case equally interesting is the fact that this white collar union worked in a company which also employed a large number of workers represented by blue collar unions, most notably the relatively powerful and practically all-male International Brotherhood of Electrical Workers. Creese contends that the presence of the IBEW inevitably shaped the behaviour of male office workers. They frequently were anxious to distance themselves from their female counterparts in the union and to establish their jobs as technical work. Male workers sought to make their work "masculine", both to ensure their sense of worth as men and fellow trade unionists, and to acquire the wages 
and benefits enjoyed by their blue collar counterparts. When unionists fought for parity, they were thinking of parity between white and blue collar workers, not between men and women within their own union.

This book is well worth the attention of those interested in industrial relations, in women in the trade movement and in the history of what trade unions actually did following World War II. While making good use of personal interviews, Creese writes the kind of thoughtful and socially relevant historical analysis that is made possible when unions ensure that their records are preserved. Indeed, Creese recognizes that the one weakness of her study is her inability to get access to equally valuable management records. She has been able to get some sense of management's position on some of these issues, but this really is an analysis that focuses on union behaviour and activity. The broader corporate and social context within which the trade union negotiated is outlined and acknowledged when necessary, but it remains shadowy at best. The reader soon becomes aware of this limitation, but it does not detract from the overall effectiveness or quality of Creese's important book.

Ken Cruikshank McMaster University

\section{Derecho sindical}

par José Manuel Lastra Lastra, $3^{e}$ édition actualisée, México : Editorial Porrúa, 1999, 308 p., ISBN 970-07-1775-5.

L'ouvrage du professeur Lastra Lastra, professeur titulaire de droit du travail à l'Université nationale autonome du Mexique (UNAM), dépasse largement la description du droit positif mexicain pour proposer une approche historique et philosophique du droit du travail, examiné surtout dans ses rapports avec la liberté et la démocratie syndicales. Dans sa préface, le professeur Néstor de Buen souligne à juste titre l'ampleur de l'ouvrage, sa rigueur et sa pertinence actuelle. Nous ajouterons que l'auteur se préoccupe aussi de philosophie du droit et de droits fondamentaux, comme le montre un autre de ses ouvrages, Fundamentos de derecho, publié chez McGraw-Hill ( ${ }^{\mathrm{e}}$ éd., 1998), qui comprend notamment tout un chapitre (IX) consacré au travail dans la Constitution mexicaine (159-220).

Cette préoccupation constante pour les principes et les normes juridiques, pour la recherche de la justice, spécialement la justice sociale, nous paraît une des caractéristiques de la doctrine juridique latino-américaine. Elle se double chez Lastra Lastra d'une vaste culture à la fois juridique et laborale, si on veut bien nous permettre cet hispanisme. Jugeons-en plutôt par les sujets qu'il aborde dans ses six premiers chapitres, consacrés au travail dans l'histoire (de l'esclavage en Grèce jusqu'aux corporations médiévales), à la révolution industrielle et au mouvement ouvrier en Angleterre, à l'évolution des corporations de métiers en France, à l'organisation corporative en Italie, au syndicalisme espagnol et au mouvement ouvrier allemand. Ce grand panorama aide à comprendre la variété des structures syndicales, de leurs idéologies et de leurs pratiques; et s'il ne nous amène pas également pour tous les pays concernés jusqu'à l'aube du XXI $\mathrm{X}^{\mathrm{e}}$ siècle, c'est que l'auteur désire surtout montrer les évolutions générales qui ont façonné le syndicalisme et le droit de ces pays.

Ce tour d'horizon international se conclut par un chapitre traitant de la doctrine sociale de l'Église catholique romaine. Rares sont les ouvrages francophones de droit du travail qui se soient préoccupés de cette dimension, alors qu'en Amérique latine l'idéologie et la 